Ankara Üniversitesi

SBF Dergisi,

Cilt 71, No. 1, 2016, s. 231 - 247

\title{
EFFECTS OF OUTWARD FOREIGN DIRECT INVESTMENT OF TURKEY ON ECONOMIC GROWTH AND DOMESTIC INVESTMENT
}

\author{
Prof. Dr. Selim Başar \\ Atatürk Üniversitesi \\ İktisadi ve İari Bilimler Fakültesi
}

\author{
Arş. Gör. Selda Ģakıcı Özkılbaç \\ Atatürk Üniversitesi \\ İktisadi ve İdari Bilimler Fakültesi
}

\begin{abstract}
The main purpose of the present study is to analyse the effects of foreign direct investment of Turkey on economic growth and domestic investment. Outside direct investments, growth, domestic investment, domestic savings and export rates between 1980 and 2011 are used as variables in this study. There are not many studies on the effects of direct investment by a country to foreign countries on the investing country's economic growth. Therefore, as far as we know, this study is the first empirical study for Turkey.

Unit-root test was applied on each variable, and bound test approach was adopted for testing cointegration according to the results of the tests. Finally, short-and-long-run relationships of variables were analysed using ARDL approach. Empirical results show that outward foreign direct investment from Turkey positively affect economic growth of Turkey, however, it does not have any short-run effects on growth while having favourable effects on investments in both short-and-long-runs.
\end{abstract}

Keywords: Outward Foreign Direct Investment, Economic Growth, Domestic Investment, Cointegration, Bound Testing

Türkiye'den Yurtdışına Yapılan Doğrudan Yabancl Yatırımların Ekonomik Büyüme ve Yurtiçi Yatırımlara Etkisi

\section{Öz}

Bu çalışmanın temel amacı, Türkiye'nin yurt dışına yaptığı doğrudan yabancı yatırımların ülkenin büyümesi ve yurt içi yatırımlar üzerine ne tür etkilerinin olduğunun analiz edilmesidir. $\mathrm{Bu}$ amaç doğrultusunda, 1980-2011 yılları arasında dışa doğrudan yabancı yatırım, büyüme, yurt içi yatırımlar, yurt içi tasarruflar ve 24 Ocak 1980 kararları ile dışa açık politika izleyen ülkemiz için önemli bir değişken olan ihracat değişkenleri kullanılmıştır. Yurt dışına yapılan doğrudan yabancı yatırımların yatırımcı ülke ekonomisine etkileri konusunda çok fazla bilimsel çalışma bulunmamaktadır. Bu nedenle bu çalışma Türkiye açısından uygulamalı ilk çalışma niteliğindedir.

Calışmada değişkenlerin her biri için birim kök testleri uygulanmıș, testlerin sonucuna göre eș bütünleşme analizi için sınır testi yaklaşımının kullanılmasına karar verilmiştir. Son olarak değişkenlerin kısa ve uzun dönem ilişkileri de ARDL yaklaşımı ile analiz edilmiştir. Tahmin sonuçlarına göre yurt dışına yapılan Doğrudan yabancı yatıımların büyümeyi kısa dönemde olumlu etkilediği, uzun dönemde herhangi bir etkisinin olmadığı; yatırımları ise kısa ve uzun dönemde olumlu etkilediği sonucuna varılmıştır.

Anahtar Sözcükler: Dışa Doğrudan Yabancı Yatırım, Ekonomik Büyüme, Yurtiçi Yatırım, Essbütünleșme, Sınır Testi

* Makale geliş tarihi: 25.11.2014

Makale kabul tarihi: 22.12.2015 


\section{Effects of Outward Foreign Direct Investment of Turkey on Economic Growth and Domestic Investment}

\section{Introduction}

Studies on the effects of foreign direct investment have started to be seen in the literature with researches on petroleum and natural gas trade, and investments made by developed countries abroad for the transfer of such resources, after the Second World War. Foreign Direct Investment (FDI) was primarily flowing from the developed countries, in where capital has been the abundant factor, to developing countries, where labor was the abundant factor. FDI was taken as an activity area of the developed countries primarily, and it has increasingly been engaged by developing countries as investing countries, from the end of 1980s. A majority of studies related to this era investigates the effects of FDI flows in the receiving countries.

While a rich literature on various aspects of FDI in the receiving countries developed over the years, there are a limited number of studies on the effects of FDI on the economy of the investing country. In recent years, especially, FDI by developing countries began to draw attention of researchers and studies on the subject have gained momentum.

In this study, the effects of FDI by Turkey, which has started to follow an outward-oriented policy with the resolutions of January 24, 1980, on economic growth and domestic investment of the country since 1980 was analyzed by means of econometric time-series.

While more studies about FDI in Turkey have focused on inward flows, outward flows of FDI in Turkey have discussed in this study.

\section{Foreign Direct Investment}

Capital is one of the most significant inputs and it is the less-abundant factor especially in developing countries. A great part of national income should be spared for investments in order to achieve and sustain economic growth. Savings are the main source of investments. The level of national income is low in developing countries and a great portion of this national income is used for consumption. As a result, required investments cannot be realized. External debt is used as a medium to overcome capital shortage resulting from low level of domestic savings. Yet, raised external debt is a short-run and costly resource due to interest. Thus, attracting FDI is a more rational, less costly and preferable policy than external indebtness. 
FDI is described as a large company's investments in countries outside its headquarters, through building of a factory, buying a currently operating production facility, or merging with another company abroad by raising its capital, with the aim of carrying out production outside the country in which it was founded (Seyidoğlu, 2001).

According to OECD, FDI include investments by a foreign investor, individual or corporate, in an incorporated firm or in an enterprise with a power of representation at a proportion of at least $10 \%$.

As understood from the descriptions above, although a transfer of capital, FDI provide entrepreneurial skills, technological facilities and transfer of organization. Because of this, foundation and equipment of enterprises are taken as investments; which include financing and high risks.

Although direction and size of FDI had changed with political and economic changes that happened in the world, FDI remains to be a very important way of investment today.

Turkey has not leant towards foreign investment issue for a long time because of negative experiences of Ottoman period due to capitulations. With The Law numbered 1567 on Protecting the Value of the Turkish Lira enacted in 1930, a number of restrictions were introduced for foreign companies entering the country (Karluk, 1999). After the Second World War, developments such as foundation of International Money Fund (IMF), Turkey's membership of the World Bank and being at the receiving end of the Marshall Plan necessitated the regulation of related legislations along with the entry of foreign capital to the country (Karluk, 1999). As a result, The Law numbered 4224 on Encouraging Foreign Investment, which was a much more liberal law by that time, was enacted in 1954 (Seyidoğlu, 2009). Considerable transformation was observed in both the world economy and and Turkish economy in 1980s. Foreign Capital Framework Decree, Numbered 8/186, published on January 24th, 1980 with fundamental, quick and permanent solutions to the country's economic problems. Such measures as minimizing bureaucracy, reducing customs tariffs, liberalization of exchange regime, signing of mutual agreements with various countries for encouragement and preservation of investments, allowing foreigners to bid in privatization have been stimulating the influx of foreign capital. Recently, Turkey is not only a recipient of FDI but also a country investing abroad itself. Turkish investors, with capital stocks gaining strength lately, have been in quest of moving abroad and benefiting from the opportunities provided by globalization (Dilek et al, 2011).

Turkey's first direct investment made abroad was achieved by İş Bankası in 1932 (Yavan, 2012). İş Bankası opened two different departments, one in Hamburg, Germany and one in Alexandria, Egypt with the aims of facilitating 
foreign trade and assisting Turkish firms in marketing their exports (Kocabaşoğlu, 2001). The sum of direct investments abroad by Turkish investors had reached to about 3,7 billion dollars by 2001. According to the Central Bank, this sum had risen to as much as 23,6 billion dollars by October 2010. According to Republic of Turkey Prime Ministry Undersecretariat of Treasury, the Central Bank and Ankara Chamber of Commerce, Turkish capital operates with approximately 3500 firms in various sectors in 103 countries. Direct investments abroad by the Turkish investors, which are approximately 24 billion dollars, are mostly concentrated in energy, banking, data and communication, manufacturing and trade sectors (Radikal, 2011).

\section{Literature Review}

There are not many studies on the effects of outward FDI (referred to as OFDI hereafter) on the economy of the investing country, yet there are quite a number of studies investigating the relationship between selected macroeconomic variables and OFDI.

Kim (2000), in his study on Korea, came to the conclusion that OFDI and inward investment increase in harmony with each other. In their study on USA, Japan, Germany and United Kingdom, Andersen and Hainaut (1998) found that OFDI has an effect of reducing inward investments. Feldstein (1994) and Desai (2005) came to the conclusion that every dollar used for FDI out of USA reduces overall domestic investments about one dollar.

Using 1970-2003 data for USA and 1971-2004 data for Germany, Herzer and Schrooten (2007) investigated the relationship between outward FDI and domestic investment in both USA and Germany to find that there has been a positive long-run effect of outward FDI on domestic investment for the US while a negative relationship in the long-run for Germany. Sauramo (2008) obtained a negative effect of FDI on domestic investment in Finland, and concluded that OFDI, rising in the long-run, has a depressing effect on domestic investments of the country. Ali J. Al-Sadig (2013) came to the conclusion that FDI has a negative effect on domestic investments.

Although there are a lot of studies concerning the relationship between FDI and economic growth, studies investigating in terms of investor country are quite limited. For example, Herzer (2008) found that there is causality between outward FDI and real GDP. On his study on Japan, Lee (2010) found a one-way (OFDI $\rightarrow$ GDP) casuality between OFDI and economic growth for Japan; but no causal relationship in short-run. SOO Khoon at all (2012), did not find any direct casual relationship between OFDI and economic growth for Malaysia. 
There are many studies on Turkey's direct investment to other countries (Batur 1994, Erbay 1996, Demirbağ et al 1998, Ekonomik Forum 1998, Akış 1999, Altay 2003, İTO 2003, Çulpan and Akçaoğlu 2003, Erdilek 2003, 2007, Batmaz 2004, Kaya 2004, Apan 2006). While a vein of Turkish literature focusing on OFDI to Turkic Republics in Central Asia and Russia (e.g. see Demirbağ et. al., 1998, Akış, 1999); another vein of research deals with investments of Turkish firms abroad (e.g. Kaya, 2004, Akçaoğlu 2005, Apan 2006) by using primary data based on surveys. Kayam ve Hiyarciklilar (2009) came to the conclusion that OFDI by Turkey are mainly horizontal investments which aims for getting access to the market; increasing with distance and exports from Turkey to host country. Akçaoğlu (2005) gave a general view of Turkish foreign investments and detailed the strategies Turkish firms follow when making investments abroad. Yavan (2012) analyzed historic development, sectoral structure and geographical distribution of direct investments abroad by Turkish firms.

\section{Data and Methodology}

Annual data over the period 1980-2011 were used and time-series analysis were performed in this study to investigate the effects of OFDI by Turkey on economic growth and on domestic investment. Annual data selected for the study contains both long-run and short-run relations. The data collected from the annual data of the Turkish Republic Central Bank, the Ministry of Development, Undersecretariat of Treasury, Turkish Statistical Institute and IMF. The data of OFDI, Fixed Capital Investments, domestic savings, imports and exports were calculated as percentages of GNP.

Table 1. Description of Data

\begin{tabular}{|l|l|l|}
\hline \multicolumn{1}{|c|}{ DATA } & \multicolumn{1}{|c|}{ DESCRIPTION } & \multicolumn{1}{c|}{ REFERANCE } \\
\hline OFDI & OUTWAR FDI/GNP & $\begin{array}{l}\text { T.C MINISTRY OF } \\
\text { DEVELOPMENT, CBRT, } \\
\text { TREASURY UNDERSECRETARY }\end{array}$ \\
\hline G & GROWTH RATE & $\begin{array}{l}\text { TURKSTAT, MINISTRY OF } \\
\text { ECONOMY }\end{array}$ \\
\hline DI & $\begin{array}{l}\text { DOMESTIG FIXED CAPITAL } \\
\text { INVESTMENT/ GNP }\end{array}$ & $\begin{array}{l}\text { IMF, MINISTRY OF } \\
\text { DEVELOPMENT }\end{array}$ \\
\hline DS & DOMESTIG SAVEING/GNP & $\begin{array}{l}\text { DPT, MINISTRY OF } \\
\text { DEVELOPMENT, IMF }\end{array}$ \\
\hline EX & EXPORT/GNP & $\begin{array}{l}\text { TURKSTAT, MINISTRY OF } \\
\text { ECONOMY }\end{array}$ \\
\hline
\end{tabular}


Descriptive statistics of variables are given in Table 2 .

Table 2. Descriptive Statistics

\begin{tabular}{|l|c|c|c|c|c|}
\hline & OFDI & G & DI & DS & EX \\
\hline Mean & 5.260 & 4.252 & 21.563 & 19.471 & 13.678 \\
\hline Median & 2.900 & 5.620 & 21.560 & 19.200 & 13.050 \\
\hline Maximum & 35.900 & 9.480 & 26.300 & 27.200 & 31.100 \\
\hline Minimum & 0.00 & -5.690 & 15.900 & 13.800 & 4.200 \\
\hline Std.Dev & 7.692 & 4.534 & 2.887 & 3.037 & 4.887 \\
\hline Jarque-Bera & 104.692 & 4.758 & 1.844 & 0.489 & 21.891 \\
\hline Probability & 0.000 & 0.093 & 0.656 & 0.798 & 0.000 \\
\hline
\end{tabular}

Graphic 1. Cusum Test Results of Variables

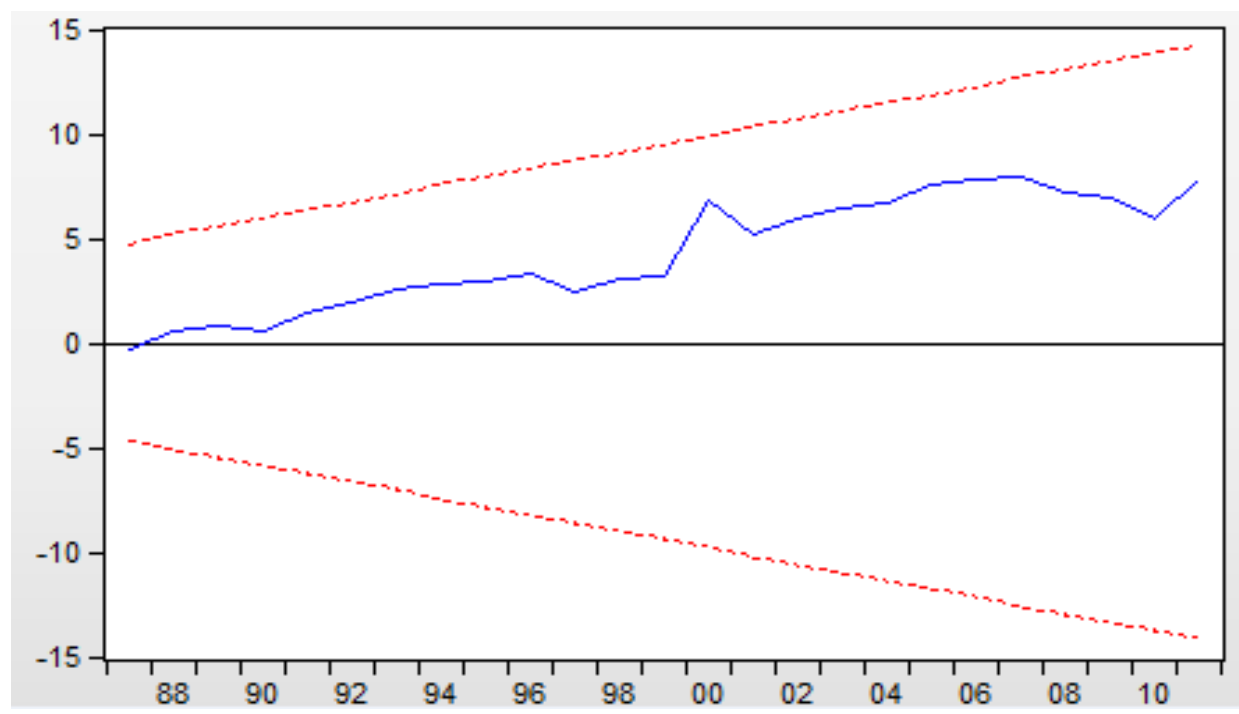

There is no structural break because the graphic is located between the red lines.

\subsection{Unit Root Analysis}

Before analyzing with time-series data, it is necessary to determine whether or not the data are stationary. Stationarity of variables used in the study was analyzed with ADF unit-root test. 
ADF test results concerning variables used in the study have been presented in Table 1, where G represents growth rates, OFDI represents FDI by Turkey; EX represents amount of exports; DI represents amount of domestic investment; DS represents domestic savings over the period 1980-2011.

Table 3. ADF Unit-Root Test Results of Variables

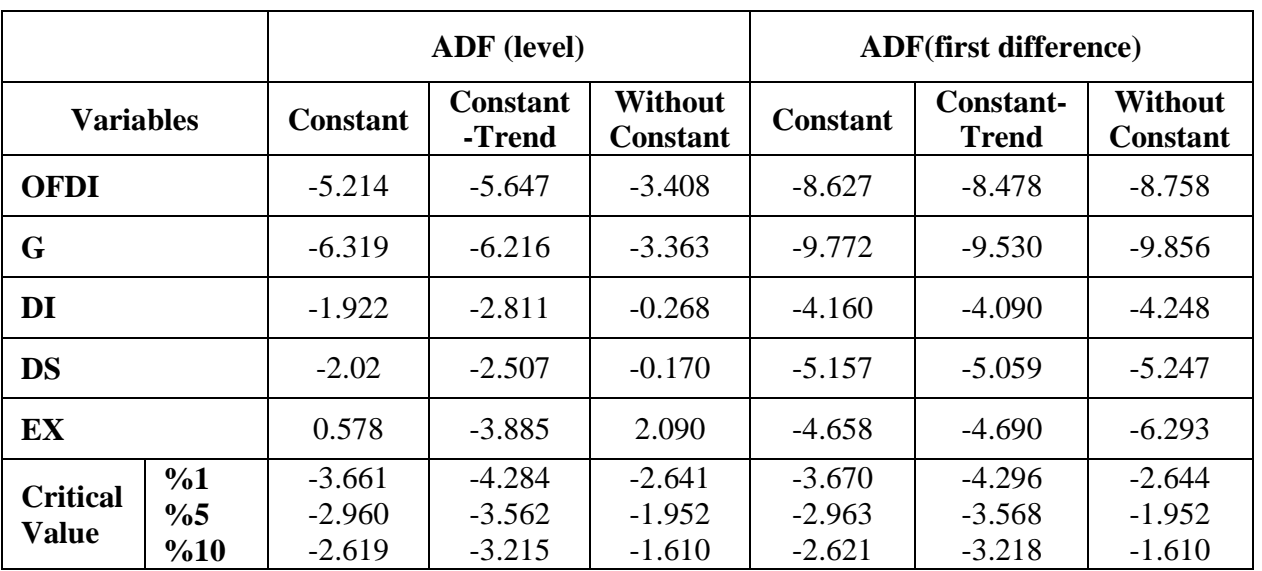

As it can be seen from Table 3, absolute values of ADF test statistics applied to original series of OFDI and $\mathrm{G}$ variables are greater than the absolute values of critical values in $1 \%, 5 \%$ and $10 \%$ level, which means that OFDI and $\mathrm{G}$ are stationary at the level; while other variables (DS, DI and EX) becoming stationary after taking first differences.

Table 4. PP Test Results of Variables

\begin{tabular}{|l|c|c|c|c|c|}
\hline & OFDI & G & DI & DS & EX \\
\hline PP düzeyde & -5.179 & -7.669 & -2.189 & -2.053 & -0.573 \\
\hline PP & -18.02 & -17.82 & -3.955 & -5.393 & -6.627 \\
Birinci fark & & & & & \\
\hline Kritik değer & -3.670 & -3.661 & -3.661 & -3.661 & -3.661 \\
$\% 1$ & -2.963 & -2.960 & -2.960 & -2.960 & -2.960 \\
$\% 5$ & -2.621 & -2.619 & -2.619 & -2.619 & -2.619 \\
\hline 10 & \multicolumn{5}{|l}{}
\end{tabular}

According to the ADF and PP test results for all variables to see longterm relationships between variables are not stable at the same level there is a need for co-integration test. 


\subsection{Bound Testing}

Bound test, developed by Pesaran, et al (2001) has two advantages over other known significant co-integration analyses (Engle and Granger, 1987, Johansen, 1988, Johansen and Juselius, 1990). First, regardless of variables being $\mathrm{I}(0)$ and $\mathrm{I}(1)$; that is, without the necessity of them being stationary at the same level; the presence of co-integration relationship between the series can be determined by the bound test. Second, this method can be applied to datasets which have few observations (Başar et al 2009; Narayan and Narayan, 2004; Şimşek and Kadılar, 2005). Long-run analysis in bound test approach is made with level value of series, however, the original states of series are conserved so that more realistic analysis can be made (Shrestha and Chowdhury, 2005). It is implemented in two stages like the method introduced by Engle and Granger (1987). By this way, whether there is a long-run relationship or not was tested.

If we construct the ARDL model in terms of the variables we have discussed, we get the following equation:

$$
\Delta \mathrm{y}_{\mathrm{t}}=\alpha+\sum \beta_{1} \Delta \mathrm{y}_{\mathrm{t}-\mathrm{i}}+\sum \beta_{2} \Delta \mathrm{x}_{1(\mathrm{t}-\mathrm{i})}+\beta_{3} \mathrm{y}_{\mathrm{t}-1}+\beta_{4} \mathrm{y}_{\mathrm{t}-1}+e_{\mathrm{t}}
$$

The basic hypothesis in this equation is $\mathrm{H}_{0}: \beta_{3}=\beta_{4}=0$. After it was determined that autocorrelation does not exist, appropriate lag lengths were investigated using AIC and SC criteria. Critical values to test related hypotheses have been presented by Pesaran (2001). Various table values are used according to the presence of a deterministic trend and restrictions on the both fixed and trend.

If it is determined that there is a long-run relationship between the variables, long- and short-run parameters are calculated and interpreted.

For a long-run relationship;

$\mathrm{y}_{\mathrm{t}}=\alpha+\sum \beta_{1} \mathrm{y}_{\mathrm{t}-\mathrm{i}}+\sum \beta_{2} \mathrm{x}+\mathrm{e}_{1}$

can be written. Then, while short-run relationship is estimated, one period of lagged value of error term obtained from long-run relationship is used:

$$
\Delta \mathrm{y}_{\mathrm{t}}=\alpha+\sum \beta_{1} \Delta \mathrm{y}_{\mathrm{t}-\mathrm{i}}+\sum \beta_{2} \Delta \mathrm{x}_{1 \mathrm{t}-\mathrm{i}}+\beta_{3} \varepsilon_{\mathrm{t}-1}+e_{2}
$$

First, lag lengths should be determined to use the bound test approach. When determining lag lengths, it is possible to utilize AIC, SBC, FPE and HQ criteria. Lag length that provides minimum critical value should be selected as the appropriate lag length for model. (Akınc1 and Yılmaz, 2013). There must be no autocorrelation in error terms for the F-test to give reliable results. As lagged values of dependent variables used $(\Delta \mathrm{G}, \Delta \mathrm{DS})$ appear in the model as independent variables, the autocorrelation test developed by Breusch and Godfrey was used instead of Durbin-Watson test (Güriş and Çağlayan, 2010). 
Then, the null hypothesis which explains that there is no long-run relationship is tested by constraining coefficients of $\mathrm{G}_{\mathrm{t}-1}$, OFDIt-1, $\mathrm{EX}_{\mathrm{t}-1}$ and $\mathrm{DI}_{\mathrm{t}-1}, \mathrm{OFDI}_{\mathrm{t}-1,}$, and $\mathrm{DS}_{\mathrm{t}-1}$ to zero, which obtained as lagged variables in models (6) and (9). The null hypothesis states that there is not any cointegration relationship between the series examined in all the tests. The coefficients belonging to the level values of variables in regression equations (6) and (9) are tested under ( $\mathrm{H} 0: \alpha 4=\alpha 5=\alpha 6=0)$ and $(\mathrm{H} 0: \beta 4=\beta 5=\beta 6=0)$ hypotheses by using simultaneous F-test. If the calculated F-statistic is greater than the value of the critical upper limit in Pesaran et. al. (2001), then the null hypothesis is rejected; if it is smaller than the lower limit value, then the null hypothesis is accepted; and if it declines to the critical limits of the values, nothing can be said about cointegration.

The maximum lag length has been taken as 4 , for each lag AIC values have been calculated for the data set used in the study is yearly. Whether or not the error terms include autocorrelation was tested applying Breusch- Godfrey autocorrelation test so that estimations can give reliable results.

\subsection{The Effect of Outward Foreign Direct Investment on Economic Growth}

The effect of OFDI on $G$ has been estimated through the following equation by using bound test approach:

$$
\begin{aligned}
\Delta \mathrm{G}_{\mathrm{t}} & =\alpha_{0}+\sum_{i=1}^{m} \alpha_{1 \mathrm{i}} \Delta \mathrm{G}_{\mathrm{t}-\mathrm{i}}+\sum_{i=0}^{m} \alpha_{2 \mathrm{i}} \Delta \mathrm{OFDI}_{\mathrm{t}-\mathrm{i}}+\sum_{i=0}^{m} \alpha_{3 \mathrm{i}} \Delta \mathrm{EX}_{\mathrm{t}-\mathrm{i}}+\alpha_{4} \mathrm{G}_{\mathrm{t}-1}+ \\
\alpha_{5} \mathrm{OFDI}_{\mathrm{t}-1} & +\alpha_{6} \mathrm{EX}_{\mathrm{t}-1}+e_{t}
\end{aligned}
$$

Table 5. Determination of the Lag Lengths

\begin{tabular}{|c|c|c|c|}
\hline Lag Length $\mathbf{m}$ & AIC & SC & B-G Autocorrelation test \\
\hline $1^{*}$ & 6.051 & 6.378 & 0.173 \\
\hline 2 & 6.143 & 6.473 & 0.220 \\
\hline 3 & 5.923 & 6.256 & $0.066^{*}$ \\
\hline 4 & 6.184 & 6.520 & 0.151 \\
\hline
\end{tabular}

Because the smallest AIC and SC values calculated that include autocorrelation, Lag length for the equation (6) has been identified as 1 . 
Table 6. Bound Test Results for Model (6)

\begin{tabular}{|c|c|c|c|c|c|}
\hline \multirow{2}{*}{$\mathbf{k}$} & F statistic & \multicolumn{2}{|c|}{$\mathbf{1 \%}$ critical value } & \multicolumn{2}{|c|}{$\mathbf{5 \%}$ critical value } \\
\hline \multirow{2}{*}{2} & \multirow{2}{*}{6.70} & $\begin{array}{c}\text { Lower } \\
\text { limit }\end{array}$ & $\begin{array}{c}\text { Upper } \\
\text { limit }\end{array}$ & $\begin{array}{c}\text { Lower } \\
\text { limit }\end{array}$ & $\begin{array}{c}\text { Upper } \\
\text { limit }\end{array}$ \\
\cline { 3 - 6 } & & 5.15 & 6.36 & 3.79 & 4.85 \\
\hline
\end{tabular}

$\mathrm{k}$ represents number of independent variables in equation (8). Critical values have been taken from Table CI (iii) in Pesaran et al (2001).

F statistical value calculated for equation (6), in which the relationship between OFDI and $\mathrm{G}$ was studied, was estimated with a lag of 1 . Comparisons of the critical values taken from Pesaran et.al. (2001) to calculated F-statistics is given in Table 6. According to Table 6 , it can be said that there is a cointegration relationship between the variables. Therefore, the ARDL model can be used to determine the short-and-long-run relationships between series. In the ARDL model, lag lengths were determined by a method suggested by Kamas and Joyce (1993) for determining the lag length in causality analysis by using AIC. The ARDL models used to estimate the long-run relationship between the variables are shown below for both equations:

$$
\begin{aligned}
& \Delta \mathrm{G}_{\mathrm{t}}=\alpha_{0+} \sum_{i=1}^{m} \alpha_{1 \mathrm{i}} \Delta \mathrm{G}_{\mathrm{t}-\mathrm{i}}+\sum_{i=0}^{m} \alpha_{2 \mathrm{i}} \Delta \mathrm{OFDIt}_{-\mathrm{i}}+\sum_{i=0}^{m} \alpha_{3 \mathrm{i}} \Delta \mathrm{EX}_{\mathrm{t}-\mathrm{i}}+e_{t} \\
& \Delta \mathrm{G}_{\mathrm{t}}=\alpha_{0}+\alpha_{1} \mathrm{EC}_{\mathrm{t}-1}+\sum_{i=0}^{m} \alpha_{2 \mathrm{i}} \Delta \mathrm{OFDI}_{\mathrm{t}-\mathrm{i}}+\sum_{i=0}^{m} \alpha_{3 \mathrm{i}} \Delta \mathrm{EX}_{\mathrm{t}-\mathrm{i}}+e_{t}
\end{aligned}
$$

ECT -1 in Model (8) stands for the one period lagged value of the error terms of series obtained from its long-run relationship. The lag lengths in model ( 8 ) were determined by means of AIC and with the method used for investigating the long-run relationship. The lag lengths in the ARDL model were determined with the help of AIC for the analysis of the long-run relationship between the variables. The ARDL ( 4,4,1) model was selected to be estimated as a result of this analysis in which the maximum lag length has been taken as 4. In Table 4, the estimation results and the long-run coefficients calculated based on these results are presented. 
Economic Growth and Domestic Investment

Table 7. The Results of the ARDL $(4,4,1)$ Model and Long-run Coefficients Calculated

\begin{tabular}{|c|c|c|}
\hline Variables & Coefficients & T statistics (p-value) \\
\hline $\mathrm{C}$ & 9.070 & $2.070(0.054)$ \\
\hline $\mathrm{G}(-1)$ & -0.153 & $-0.678(0.507)$ \\
\hline $\mathrm{G}(-2)$ & -0.249 & $-0.041(0.313)$ \\
\hline $\mathrm{G}(-3)$ & -0.183 & $-0.649(0.525)$ \\
\hline $\mathrm{G}(-4)$ & -0.491 & $-2.276(0.036)$ \\
\hline OFDI & -0.061 & $0.466(0.646)$ \\
\hline OFDI $(-1)$ & -0.178 & $-1.360(0.192)$ \\
\hline OFDI(-2) & -0.151 & $-0.978(0.343)$ \\
\hline OFDI $(-3)$ & -0.233 & $-1.398(0.181)$ \\
\hline OFDI(-4) & -0.109 & $0.608(0.551)$ \\
\hline EX & -0.197 & $-0.552(0.588)$ \\
\hline $\mathrm{EX}(-1)$ & -0.350 & $0.653(0.522)$ \\
\hline $\begin{array}{l}\mathrm{R}^{2}=049 \\
\mathrm{R}^{2}=0.14\end{array}$ & $\begin{array}{l}F(P)=1.402(0.261) \\
D W=2.307\end{array}$ & $\begin{array}{l}X_{B G}^{2}=2.426(0.119) \\
X^{2}{ }_{\text {White }}=12.984(0.294)\end{array}$ \\
\hline \multicolumn{3}{|c|}{ Long-run Equation Accounted by ARDL } \\
\hline Variable & Coefficient & t- statistics \\
\hline $\mathrm{C}$ & 3.963 & 0.113 \\
\hline OFDI & 0.117 & 0.145 \\
\hline EX & -0.247 & 0.806 \\
\hline
\end{tabular}

According to the results of the long-run equation in Table 7, there is a negative but statistically insignificant correlation between growth and lagged values of both OFDI and growth, while there is a negative and statistically significant relationship between the level and lagged value and growth. Thus, it can be said that there is not a significant relationship between OFDI and growth in the long-run.

The short-run relationship between the variables was investigated by an error correction model based on the ARDL equation (7). As the data are annual, the maximum lag length was taken as 4 in the model and it has been concluded that the relationship with short-run must be tested by the ARDL $(1,0,0)$ model. The estimation results of this model are shown in Table 3.8. 
Table 8. Error Correction Model Results Based on the ARDL Approach

\begin{tabular}{|l|c|c|}
\hline \multicolumn{1}{|c|}{ Variables } & Coefficients & t-statistics (prob) \\
\hline $\mathrm{C}$ & 0.093 & $0.102(0.919)$ \\
\hline $\mathrm{D}(\mathrm{G}(-1))$ & -0.226 & $-1.431(0.166)$ \\
\hline $\mathrm{D}(\mathrm{OFDI})$ & 0.250 & $3.138(0.004)$ \\
\hline $\mathrm{D}(\mathrm{EX})$ & -0.320 & $-1.018(0.319)$ \\
\hline $\mathrm{EC}(-1)$ & -1.053 & $-3.497(0.002)$ \\
\hline
\end{tabular}

\subsection{The Effect of Outward FDI on Domestic Investments}

Secondly, the effect of OFDI on domestic investments is investigated using bound test by using equation (9).

$$
\begin{aligned}
& \Delta \mathrm{DI}=\beta_{0}+\sum_{i=1}^{m} \beta_{\mathrm{li}} \Delta \mathrm{DI}_{\mathrm{t}-\mathrm{i}}+\sum_{i=0}^{m} \beta_{2 \mathrm{i}} \Delta \mathrm{OFDI}_{\mathrm{t}-1}+\sum_{i=0}^{m} \beta_{3 \mathrm{i}} \Delta \mathrm{DS}_{\mathrm{t}-\mathrm{i}}+\beta_{4} \mathrm{DI}_{\mathrm{t}-1}+ \\
& \beta_{5} \mathrm{OFDI}_{\mathrm{t}-1}+\beta_{6} \mathrm{DS}_{\mathrm{t}-1}+e_{t}
\end{aligned}
$$

Table 9. Bound Test Results for the Model (9)

\begin{tabular}{|c|c|c|c|c|c|}
\hline \multirow{2}{*}{$\mathbf{k}$} & F statistics & \multicolumn{2}{|c|}{$\mathbf{1 \%}$ critical value } & \multicolumn{2}{|c|}{$\mathbf{5 \%}$ critical value } \\
\hline \multirow{2}{*}{2} & \multirow{2}{*}{6.14} & $\begin{array}{c}\text { Lower } \\
\text { limit }\end{array}$ & $\begin{array}{c}\text { Upper } \\
\text { limit }\end{array}$ & $\begin{array}{c}\text { Lower } \\
\text { limit }\end{array}$ & $\begin{array}{c}\text { Upper } \\
\text { limit }\end{array}$ \\
\cline { 3 - 6 } & & 5.15 & 6.36 & 3.79 & 4.85 \\
\hline
\end{tabular}

$\mathrm{k}$ represents number of independent variables in equation (8). Critical values have been taken from Table CI (iii) in Peseran et al (2001).

The F statistical value calculated after the equation (9), in which the relationship between OFDI and domestic investments was investigated, was estimated with a lag of 1. Comparisons of the critical values taken from Pesaran et.al. (2001) to calculated F-statistics is given in Table 6. Again, it can be said that there is a cointegration relationship between the variables as well and the ARDL model can be used to determine the short-and-long-run relationships between series. 
According to Table 9, there is a positive and statistically significant relationship between OFDI and growth in the short-run. Thus, it can be said that, OFDI have the effect of enhancing growth in the short-run.

The short-and-long-run coefficients are estimated for equations (10) and (11) are given in the tables below.

$$
\begin{aligned}
& \Delta \mathrm{DI}_{\mathrm{t}}=\beta_{0+} \sum_{i=1}^{m} \beta_{1 \mathrm{i}} \Delta \mathrm{DI}_{\mathrm{t}-\mathrm{i}}+\sum_{i=0}^{m} \beta_{2 \mathrm{i}} \Delta \mathrm{OFDIt}_{-\mathrm{i}}+\sum_{i=0}^{m} \beta_{3 \mathrm{i}} \Delta \mathrm{DS}_{\mathrm{t}-\mathrm{i}}++e_{t} \\
& \Delta \mathrm{DI}_{\mathrm{t}}=\beta_{0}+\beta_{1} \mathrm{EC}_{\mathrm{t}-1}+\sum_{i=0}^{m} \beta_{2 \mathrm{i}} \Delta \mathrm{OFDI}_{\mathrm{t}-\mathrm{i}}+\sum_{i=0}^{m} \beta_{3 \mathrm{i}} \Delta \mathrm{DS}_{\mathrm{t}-\mathrm{i}}+e_{t}
\end{aligned}
$$

Above-mentioned procedures for model (8) are repeated for $t$ model (10), and the ARDL ( $1,1,0)$ model was selected to be estimated and the estimation results are given in Table 10.

Table 10. The Results of ARDL $(1,1,0)$ model and Calculated Long-run Coefficients

\begin{tabular}{|l|l|l|}
\hline Variable & Coefficient & t- statistics (prob) \\
\hline $\mathrm{C}$ & 5.683 & $1.189(0.245)$ \\
\hline $\mathrm{I}(-1)$ & 0.194 & $0.919(0.366)$ \\
\hline OFDI & 0.067 & $2.027(0.053)$ \\
\hline OFDI(-1) & 0.0003 & $0.008(0.993)$ \\
\hline $\mathrm{S}$ & 0.584 & $3.864(0.0007)$ \\
\hline $\mathrm{R}^{2}=0.81$ & $\mathrm{~F}(\mathrm{p})=20.56(0.000)$ & $X^{2}{ }_{\mathrm{BG}}=3.507(0.173)$ \\
$\mathrm{R}^{2}=0.77$ & $\mathrm{DW}=1.633$ & $X_{\text {WHiTE }}=7.29(1.998)$ \\
\hline Long-run equation & \multicolumn{2}{|l|}{} \\
\hline Variable & Coefficient & $\mathrm{t}$-statistics \\
\hline OFDI & 0.059 & 1.21 \\
\hline $\mathrm{S}$ & 0.706 & 5.657 \\
\hline $\mathrm{C}$ & 7.479 & 2.962 \\
\hline
\end{tabular}

According to the results of the second ARDL model, in which the longrun relationship between domestic investment and OFDI and domestic investment and domestic savings was tested, there is a positive and statistically significant relationship between the one-period lagged value of domestic investment and domestic investment itself. There is a positive and significant 
relationship between the values of level and difference of OFDI, and a positive but statistically insignificant relationship between the values of level and difference of domestic investment. There is also a positive and statistically significant relationship between domestic savings and domestic investment. That allows us to conclude that OFDI increases domestic investment in the long-run. The short-run relationship results of the same model are given in Table 11.

Table 11. Short-run Relationship Results -ARDL $(1,0,0)$

\begin{tabular}{|l|l|l|}
\hline Variable & Coefficient & t-statistics (prob) \\
\hline $\mathrm{C}$ & 0.038 & $0.135(0.893)$ \\
\hline $\mathrm{D}(\mathrm{I}(-1))$ & 0.191 & $0.81980 .420)$ \\
\hline $\mathrm{D}(\mathrm{OFDI})$ & 0.071 & $2.598(0.015)$ \\
\hline $\mathrm{D}(\mathrm{S})$ & 0.599 & $4.064(0.000)$ \\
\hline $\mathrm{ECT}(-1)$ & -0.168 & $-6.688(0.000$ \\
\hline
\end{tabular}

According to the results in Table 11, there is a positive and significant relationship between OFDI and domestic investments in the short-run, as well. Accordingly, OFDI can be said to increase domestic investment in the shortrun.

\section{Conclusion}

Foreign Direct Investment, having been a perennial movement of capital, has become widespread among the countries in recent years. FDI, which was flowing only from developed countries to developing countries, has become an important area of economic activity. Today, FDI flows can be seen among developing countries, even some less-developed countries have become investing countries in the global economy. There is quite an extensive literature on this subject. Studies conducted on FDI have mostly dealt with the effects of FDI to the recipient country. There are many studies that investigate the effects of influx of FDI on the Turkish economy. However, there are not many studies investigating the effects of OFDI on the economy of investing country. Limited number of studies on this topic has mostly focused on developing countries. Empirical literature has mostly been concentrating on causality. Turkey has been receiving FDI within the framework of the outward-oriented policies followed by Turkey since 24 January 1980. The country has become an investing nation itself throughout the years. While OFDI from Turkey was 
previously limited to a few countries on a small scale, in recent years, more than 3,000 Turkish investors carry out investments in 109 different countries around the world, including Vietnam, Iraq, Panama, Sri Lanka, Brazil, Angola, Germany, Malta and so on.

In this study, the effects of OFDI by Turkey on growth and domestic investment have been investigated. This study is important as there have not been any empirical studies on this issue so far. Empirical studies available in the literature have rarely mentioned cointegration relationship. Therefore, contegration between series has been investigated in this study. As the unit-root test results suggest, variables are not static at the same level. Cointegration relationship has been investigated using bounds testing approach. According to the results of estimation, it has been concluded that OFDI from Turkey has had a positive impact on growth in the short-run; on the other hand, it has not had a significant impact in the long-run. Similarly, it has been observed that OFDI has had a positive impact on domestic investments in the short- and long-run. By the estimation results, it can be said that OFDI have had a positive effect on domestic investment, creating a positive impact on unemployment through transfer of profits and employment of the unemployed youths abroad in areas where investments are realized. As a result, growth can be said to be affected positively.

\section{References}

Akçaoğlu, Emin (2005), Türk Firmalarının Dış Yatırımları: Saikler ve Stratejiler (İstanbul: Türkiye Bankalar Birliği, Yayın No. 241).

Andrea, Goldstein (2007), "Multinational Companies from Emerging Economies" Indian Journal of Industrial Relations, 45: 137-147

Akıncı, Merter ve Ömer Yılmaz (2013), "Türkiye Ekonomisinde Üçüz Açık Hipotezinin Geçerliliği; Sınır Testi Yaklaşımı”, IMKB Dergisi, 50: 1-26.

Akiş, Yeşim T. (1999), “Turkish Firms' Success Factors in the Former Soviet Union”, Cross Cultural Management: An International Journal, 6: 3-10.

Ali, J. Al-Sadig (2013), "Outward Foreign Direct Investment and Domestic Investment: The Case of Developing Countries" IMF Working Paper, Middle East and Central Asia Department, 13 (52): $1-27$.

Altay, Hüseyin (2003), "Orta Asya Türk Cumhuriyetleri'ne Yapılan Sermaye Transferlerine Etki Eden Ekonomik Faktörlerin Türkiye Kökenli Uluslararası Firmaların Yöneticileri Açısından Değerlendirilmesi”, Balıkesir Üniversitesi Sosyal Bilimler Enstitüsü Dergisi 6: 1-23.

Apan, Evrim (2006), Türkiye'nin Yurt Dışına Doğrudan Yatııımları ve Türk Firmalarının Doğrudan Dış Yatııım Kararlarını Etkileyen Faktörler, Uzmanlık Tezi (Ankara: Hazine Müsteşarlığı). 
Batur, M. Erhan (1994), Yurt Dışı Sermaye Yatırımları ve Yabancı Sermayeden Türk Ekonomisinin Beklentileri, Uzmanlık Tezi (Ankara: Hazine ve Dış Ticaret Müsteşarlığı).

Batmaz, Nihat ve Sevinç Tekeli (2009), Doğrudan Yabancı Sermaye Yatırımlarının Ekonomik Büyüme Üzerine Etkileri (Denizli: Ekim Basım Yayın Dağıtım).

Çapraz, İlkay ve İpek Demircioğlu (2003), Türkiye'den Yurt Dışına Doğrudan Sermaye Yatırımları ve Türk Yatırımcıları (İstanbul Ticaret Odası Yayınları).

Çulpan, Refik ve Akçaoğlu Emin (2003), "An Examination of Turkish Direct Investments in Central Eastern Europe and Commonwealth of Independent States", Marinova, Svetla T. ve Marin A. Marinov (Eds.), Foreign Direct Investmentin Central and Eastern Europe (Aldershot: Ashgate 181-199).

Desai, Mihir C., Fritz Foley and R. Hines Jr. James (2005), "Foreign Direct Investment and Domestic Capital Stock", American Economic Review Papers and Proceeding, 95: 33-38.

Engel, Robert F. and C.W.J. Granger (1987), "Co-integration and Error Correction Representation, Estimation and Testing", Econometrica, 55 (2): 251-276.

Erbay, Yusuf (1996), Küresel İşletmelerin Yönetimi ve Türk İşletmelerinin Yeni Türk Cumhuriyetlerine Yönelik Faaliyetleri (Ankara: Mahalli İdareler Genel Müdürlüğü)

Erdilek, Asım (2003), "A Comparative Analysis of Inward and Outward FDI in Turkey: Transnational Corporations", Iktisat Işletme ve Finans Dergisi, 12: 79-105.

Granger, C. W. J. and P. Newbold (1974), "Spurious Regressions in Econometrics", Journal of Econometrics, 12 (2): 111-120.

Güriş, Selahattin ve Ebru Çağlayan (2010), Ekonometri: Temel Kavramlar (İstanbul: Der Yayınları).

Herzer, Dierk (2012), "The Long-Run Relationship between Outward FDI and Total Factor Productivity: Evidence for Developing Countries", International Economic Journal, 1: 155174.

Herzer, Dierk and Mechthild Schrooten (2007), "Outward FDI and Domestic Investment", German Institute for Economic Research (Berlin): 1-14.

Johansen, Soren and Katarina Juselius (1990), "Maximum Likelihood Estimation and Inference on Cointegration - with Applications to the Demand for Money", Oxford Bulletin of Economics and Statistics, 52 (2): 169-210.

Karluk, Rıdvan (1999), Türkiye Ekonomisi: Tarihsel Gelişim, Yapısal ve Siyasal Değişim (İstanbul: Beta Yayınları).

Kaya, Harun (2004), "Internationalization of Tukish Manufacturing Firms: Foreign Direct Investment Outflow. Unpublished PhD Dissertation" Institute of Social Sciences. Istanbul: Bosporus University.

Kayam, Saime Suna ve Mehtap Hisarciklar (2009), "Türkiye'den Çıkan Doğrudan Yabancı Yatırımları Belirleyen Etmenler", Iktisat, İşletme ve Finans Dergisi, 24 (208): 47-70.

Kim Ki, David Deok and Seo Jung-Soo (2000), "Foreign Direct Investment, Domestic Investment, and Economic Growth in Korea: Interpreting Empirical Evidence", Korea-Australasia Research Centre, University of New South Wales: 1-18.

Kocabaşoğlu, Uğur (2001), Türkiye Iş̧ Bankası Tarihi (İstanbul: İş Bankası Kültür Yayınları).

Lee, Chew Ging (2010), "Outward Foreign Direct Investment and Economic Growth: Evidence from Japan", Global Economic Review: Perspectives on East Asian Economies and Industries, 39 (3): 317-326.

Narayan, S. and P.K. Narayan (2004), "Determinats of Demand of Fijis Exports: An Empirical Investigation", The Developing Economics, 17 (1): 95-112. 
Economic Growth and Domestic Investment

OECD, http://www.oecd.org/document/0,3746,en2649_201185_46462759_1_1_1_1,0 (30.03.2012).

Pesaran, M. Hashem, Yongcheol Shin and Richard J. Smith (2001), "Bounds Testing Approaches to the Analysis of Level Relationships", Journal of Applied Econometrics, 16: 289-326.

Radikal, http://www.radikal.com.tr/radikal.aspx?atype=haberyazdir\&articleid=103650 (14.01.2014).

Ramkishen, S. Rajan, Rajiv Kumar ve Nicola Virgill (Eds.) (2008), New Dimensions of Economic Globalization: Surge of Outward Foreign Direct Investment From Asia (World Scientific Publishing Co Pte Ltd.).

Seyidoğlu, Halil (2009), Uluslararası Finans (İstanbul: Gözlem Yayınları).

Soo, Khoon Wong, Koi Nyen and Tham, SIEW Yean Cen PRIS (2012), Does Outward FDI Matter in International Trade? Evidence from Malaysia, University Sains Malaysia, Business School, Sunway University, Malaysia, Institute of Malaysian and International Studies, Universiti Kebangsaan Malaysia: 1-18.

Stevens, Guy V.G. and Robert Lipsey (1992), "Interactions Between Domestic and Foreign Investment", Journal of Money and Finance, 11: 40-62 .

Şimşek, Muammer ve Cem Kadilar (2004), “Türkiye'nin İthalat Talebi Fonksiyonunun Sınır Testi Yaklaşımı ile Eş bütünleşme Analizi: 1970-2002", Doğuş Üniversitesi Dergisi, 5 (1): 2734.

Şimşek, Muammer ve Cem Kadılar (2005), “Türkiye'nin İhracat Talebi Fonksiyonunun Sınır Testi Yöntemi İle Eşbütünleşme Analizi”, Doğuş Üniversitesi Dergisi, 6 (1): 144-152.

Yavan, Nuri (2012), “Türkiye'nin Yurt Dışındaki Doğrudan Yatırımları: Tarihsel ve Mekânsal Perspektif", Bilgi Yayınları, 63: 237-270.

Yu, Chao and Ye Zhou (2010), "Effects of China's Outward FDI on Domestic Employment", 10th International Sempoziyum on Distribudet Computing and Applications to Business, Engineering and Science: 137-141. 